\title{
KEMAMPUAN MENGIDENTIFIKASI NILAI-NILAI DAN KEBAHASAAN YANG TERKANDUNG DALAM CERPEN SISWA KELAS X SMA SWASTA PELITA BULU CINA TAHUN PELAJARAN 2018/2019
}

\author{
Maya Afriani' ${ }^{1}$, Juwita Erdaini ${ }^{2}$, Sanimah $^{3}$ \\ STKIP BUDIDAYA BINJAI
}

\begin{abstract}
ABSTRAK
Tujuan penelitan ini adalah untuk mengetahui kemampuan mengidentifikasi nilai-nilai dan kebahasaan yang terkandung dalam cerpen siswa kelas X SMA Swasta Pelita Bulu Cina tahun pelajaran 2018/2019. Populasi dalam penelitian ini adalah seluruh siswa kelas X SMA Swasta Pelita Bulu Cina tahun pelajaran 2018/2019 yang berjumlah 32 orang. Sampel dalam penelitian ini sebanyak 32 orang. Metode yang digunakan dalam penelitian ini adalah metode deskriptif kuantitatif. Instrumen yang digunakan adalah tes mengidentifikasi nilai-nilai dan kebahasaan yang terkandung dalam cerpen dalam bentuk tes uraian. Nilai rata-rata kemampuan mengidentifikasi nilai-nilai dan kebahasaan yang terkandung dalam cerpen adalah 81,55. Dengan demikian dapat diketahui bahwa siswa kelas XI Madrasah Aliyah Swasta Al Maksum Stabat tahun pelajaran 2018/2019 dapat menulis cerpen dengan baik.
\end{abstract}

Kata Kunci: Nilai-Nilai dan Kebahasaan, Cerpen

\section{PENDAHULUAN}

Bahasa memiliki peranan yang sangat signifikan dalam kehidupan sehari-hari. Tanpa adanya bahasa, manusia tidak dapat mengungkapkan perasaan, menyampaikan keinginan, memberikan saran atau pendapat, dan lain sebagainya. Semakin tinggi tingkat penguasaan bahasa seseorang akan berbanding lurus dengan penggunaannya dalam kehidupan sehari-hari. Hal ini menunjukkan betapa pentingnya peran bahasa sebagai alat menyampaikan hasil karya kepada orang lain.

Karya sastra merupakan salah satu bentuk komunikasi yang disampaikan melalui bahasa. Selain menyajikan paparan peristiwa secara menarik serta nilai-nilai estetik yang disampaikan secara implisit, sastra juga mampu mengajak pembaca untuk berkontemplasi menemukan nilainilai kekompleksitasan secara mendalam. Bahasa yang digunakan pengarang dalam membuat karya sastra mempunyai nilai estetika yang sangat tinggi. Sehingga membuat penikmat karya sastra dapat merasakan keindahan serta pesan tersirat yang ingin disampaikan pengarang dan dapat menjadi tuntunan hidup. Sering kali pengarang menggunakan bahasa yang berbeda-beda dan bahasa tersebut memang sengaja diolah sedemikian rupa oleh pengarang untuk menghasilkan estetika pada penggunaan bahasa.

Karya sastra dapat dibagi atas puisi, drama dan prosa. Puisi bersifat bebas namun terikat, drama berupa naskah yang dipentaskan, sedangkan prosa bersifat bebas dan tidak terikat. Prosa merupakan karya sastra yang berbentuk cerita, dengan menggunakan medium bahasa yang sifatnya tidak terikat oleh bait dan baris. Prosa pun terbagi menjadi dua yaitu prosa baru dan prosa lama. Prosa baru memiliki bentuk seperti cerpen, roman, novel, riwayat, kritik dan resensi. Sedangkan prosa lama memiliki bentuk seperti hikayat, sejarah, kisah dan dongeng.

Cerpen merupakan sebuah karya sastra. Cerpen merupakan karya sastra yang mengupas tentang kehidupan manusia ataupun seseorang dalam menghadapi persoalan dengan orang-orang, lingkungan dan dirinya sendiri. Notosusanto dalam Tarigan, mengatakan bahwa "Cerita pendek 
adalah cerita yang panjangnya sekitar 5000 kata atau kira-kira tujuh belas halaman kuarto spasi rangkap yang terpusat dan lengkap pada dirinya sendiri".

Sebagai sebuah karya sastra, cerpen memiliki nilai-nilai dalam kehidupan yang patut untuk diteladani. Nilai-nilai kehidupan tersebut biasanya dimiliki oleh tokoh yang bersifat protagonis dalam sebuah cerpen. Dengan memahami nilai-nilai yang terkandung dalam cerpen tersebut, diharapkan siswa dapat meneladani sifat-sifat positif yang dimiliki dari setiap tokoh dalam cerpen dan dapat diterapkan dalam kehidupan.

Pada kurikulum 2013, Pada Standar Kompetensi 3.8. Membandingkan nilai-nilai dan kebahasaan yang terkandung dalam cerpen, dengan materi pelajaran Menjelaskan persamaan dan perbedaan isi dan nilai-nilai dalam cerpen dan cerita rakyat. Melalui pembelajaran ini, siswa diharapkan mengetahui serta mampu membandingkan nilai-nilai dan kebahasaan cerita rakyat dan cerpen.

Berdasarkan observasi yang peneliti lakukan di SMA Swasta Pelita Bulu Cina, ditemukan bahwa kemampuan siswa mengidentifikasi nilai-nilai dan kebahasaan dalam cerpen masih rendah. Hal ini diketahui dari nilai rata-rata ulangan harian pada materi mengidentifikasi nilai-nilai dan kebahasaan dalam cerpen yaitu sebesar 63. Nilai ini masih jauh di bawah nilai KKM yang telah ditentukan oleh sekolah yaitu 75. Ketertarikan siswa dalam mengikuti materi pelajaran mengidentifikasi nilai-nilai dan kebahasaan dalam cerpen masih rendah, hal ini dikarenakan siswa kesulitan untuk menemukan nilai-nilai yang terkandung dalam cerpen. Di samping kesulitan siswa menemukan nilai-nilai yang terkandung dalam cerpen, siswa juga kesulitan dalam menemukan penggunaan majas dan konjungsi yang ada dalam cerpen.

Berdasarkan uraian di atas, maka peneliti tertarik untuk melakukan penelitian dengan judul "Kemampuan Mengidentifikasi Nilai-Nilai dan Kebahasaan yang Terkandung Dalam Cerpen Siswa Kelas X SMA Swasta Pelita Bulu Cina Tahun Pelajaran 2018/2019”.

\section{METODE}

Penelitian ini dilaksanakan di SMA Swasta Pelita Bulu Cina yang beralamat di jalan Bulu Cina Dusun Emplasmen B Kecamatan Hamparan Perak Kabupaten Deli Serdang.

Penelitian ini dilaksanakan pada semester ganjil tahun pelajaran 2018/2019. Adapun rencana pelaksanaan penelitian ini terlihat pada tabel berikut.

Tabel 3.1

\begin{tabular}{|c|c|c|c|c|c|c|c|c|c|}
\hline \multirow{2}{*}{ Kegiatan } & \multicolumn{9}{|c|}{ Bulan/T ahun 2018} \\
\hline & Mar & April & Mei & Juni & Juli & Agt & Sept & Ols & Now \\
\hline Observasi awal & $\sqrt{1}$ & & & & & & & & \\
\hline Perencanaan & & $\sqrt{ }$ & & & & & & & \\
\hline Bimbingan Proposal & & & $\sqrt{ }$ & $\sqrt{ }$ & $\sqrt{ }$ & & & & \\
\hline Seminar Proposal & & & & & & $\sqrt{ }$ & & & \\
\hline Pengumpulan Data & & & & & & $\sqrt{ }$ & $\sqrt{ }$ & & \\
\hline Sidang Meja Hijau & & & & & & & & $\sqrt{1}$ & \\
\hline
\end{tabular}

Adapun populasi dalam penelitian ini adalah keseluruhan siswa kelas X SMA Pelita Bulu Cina tahun pelajaran 2018/2019 sebanyak 32 orang. Pengambilan sampel harus dilakukan sedemikian rupa sehingga diperoleh sampel yang benar-benar dapat berfungsi sebagai contoh atau dapat menggambarkan keadaan populasi sebenarnya. Dengan istilah lain, sampel harus representatif. Adapun sampel dalam penelitian ini yaitu seluruh siswa kelas X SMA Pelita Bulu Cina yang berjumlah 32 orang. 
Metode penelitian merupakan suatu cara untuk mencari kebenaran dengan mengumpulkan data dan menganalisis data yang diperlukan untukan mencapai tujuan. Menurut Arikunto mengatakan, "Metode penelitian adalah strategi umum yang dianut dalam pengumpulan dan analisis data yang diperlukan guna menjawab persoalan yang dihadapi".

Jenis penelitian dalam penelitian ini merupakan penelitian Kuantitatif. Penelitian ini menggunakan tipe penelitian deskriptif dengan pendekatan kuantitatif. Sugiyono menyatakan, "Penelitian deskriptif yaitu, penelitian yang dilakukan untuk mengetahui nilai variabel mandiri, baik satu variabel atau lebih (independen) tanpa membuat perbandingan, atau menghubungkan dengan variabel yang lain".

Berdasarkan teori tersebut, penelitian deskriptif kuantitatif, merupakan data yang diperoleh dari sampel populasi penelitian dianalisis sesuai dengan metode statistik yang digunakan. Penelitian deskriptif dalam penelitian ini dimaksudkan untuk mendapatkan gambaran dan keterangan-keterangan mengenai Kemampuan Mengidentifikasi Nilai-Nilai dan Kebahasaan yang Terkandung Dalam Cerpen Siswa Kelas X SMA Swasta Pelita Bulu Cina Tahun Pelajaran 2018/2019.

Untuk menghindari terjadinya kesalahpahaman serta untuk memperjelas permasalahan yang dibahas, maka perlu dirumuskan defenisi operasional variabel penelitian. Adapun definisi operasional dalam penelitian ini adalah:

1. Nilai-nilai dalam cerpen yaitu nilai-nilai kehidupan berupa nilai agama, nilai moral, nilai budaya, nilai sosial, dan nilai pendidikan.

2. Kebahasaan dalam cerpen yaitu penggunaan majas dan konjungsi.

Penelitian dilakukan terhadap data. Chaer menyatakan bahwa, "Untuk mendapatkan data itu diperlukan adanya alat pengambil data yang biasa disebut dengan istilah instrumen penelitian". Instrumen dalam penelitian ini adalah berbentuk tes uraian mengidentifikasi nilai-nilai dan kebahasaan dalam cerpen siswa kelas X SMA Swasta Pelita Bulu Cina. Berikut ini adalah kriteria penilaian yang digunakan untuk menilai kemampuan mengidentifikasi nilai-nilai dan kebahasaan dalam cerpen.

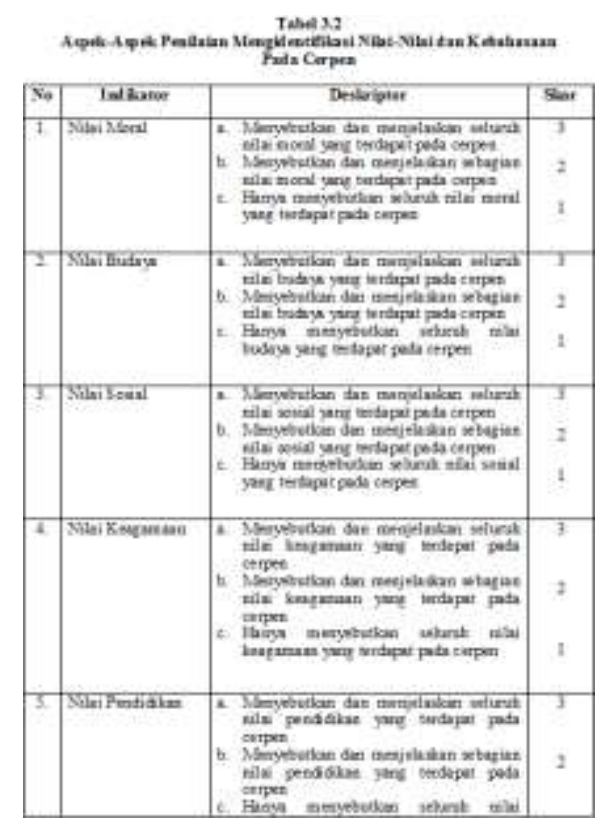


Untuk merubah nilai dalam bentuk kategori, maka digunakan kriteria sebagai berikut:

Tabel 3.3

Rentang Skor dan Kategori Penilaian Mengid entifikasi

Nilai-Nilai dan Kebahasaan Pada Cerpen

\begin{tabular}{|c|c|c|}
\hline Kategori & Penilaian & Hur uf \\
\hline Sangat Baik & $85-100$ & A \\
\hline Baik & $70-84$ & B \\
\hline Cukup & $60-69$ & C \\
\hline Kurang & $50-59$ & D \\
\hline Sangat Kurang & $0-49$ & E \\
\hline Sumber: Sudÿono &
\end{tabular}

Penelitian ini merupakan penelitian deskriptif kuantitatif dengan tahapan yaitu mengumpulkan data, memproses/ memproduksi data, menyajikan data, dan menyimpulkan hasil proses data. Prosedur penelitian dapat dilihat pada gambar berikut.

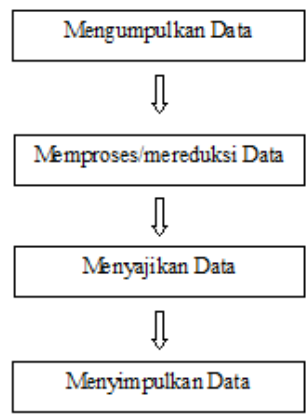

Data adalah bagian terpenting dari suatu penelitian, karena dengan data peneliti dapat mengetahui hasil dari penelitian tersebut. Pada penelitian ini, data diperoleh dari berbagai sumber, dengan menggunakan teknik pengumpulan data yang bermacam-macam dan dilakukan secara terus menerus sampai datanya jenuh. Sesuai dengan karakteristik data yang diperlukan dalam penelitian ini, maka teknik pengumpulan data yang dilakukan dengan menggunakan tes. Tes yang dimaksud yaitu data-data hasil tes siswa pada materi mengidentifikasi nilai-nilai dan kebahasaan cerita rakyat dan cerpen siswa kelas X SMA Swasta Pelita Bulu Cina tahun pelajaran 2018/2019.

Data-data hasil penelitian secara deskriptif yaitu menganalisis data-data yang terdapat dalam tabel-tabel data. Adapun langkah-langkah dalam menganalisis data adalah:

1. Mentabulasi skor yang diperoleh siswa

Caranya dengan membuat tabel dan mentabulasi skor nilai evaluasi siswa pada penulisan teks laporan hasil observasi.

2. Menghitung nilai rata-rata hasil belajar

Setelah dianalisis melalui tabel skor nilai, maka selanjutnya hasil tersebut dianalisis dengan menggunakan rumus :

$$
\bar{X}=\frac{\sum \mathrm{fi}_{1}}{\sum \mathrm{fi}}
$$

Dimana :

$\overline{\mathrm{X}} \quad=$ nilai rata-rata hasil belajar

$\sum$ fi $x_{1} \quad=$ jumlah semua harga $x$ (nilai) 
Tabel 4.2

Distribusi Kriteria Kema mpuan Mengid entifikasi Nilai-Nilai d an Kebahasaan dalam Cerpen Pada Indikator Nilai Moral

\begin{tabular}{|c|l|c|c|}
\hline No & Deskriptor Penilaian $(X)$ & Frekuensi (F) & Persentase \\
\hline 1 & $\begin{array}{l}\text { Menyebutkan dan } \\
\text { menjelaskan seluruh } \\
\text { nilai moral yang } \\
\text { terdapat pada cerpen }\end{array}$ & 13 & $40,63 \%$ \\
\hline 2 & $\begin{array}{l}\text { Menyebutkan dan } \\
\text { menjelaskan sebagian } \\
\text { nilai moral yang } \\
\text { terdapat pada cerpen }\end{array}$ & 19 & 59,38 \\
\hline 3 & $\begin{array}{l}\text { Hanya menyebutkan } \\
\text { seluruh nilai moral yang } \\
\text { terdapat pada cerita } \\
\text { rakyat dan cerpen }\end{array}$ & 0 & $0 \% 6$ \\
\hline & Jumlah & 32 & $100 \% 6$ \\
\hline
\end{tabular}

$\sum \mathrm{fi} \quad=$ jumlah semua siswa

3. Menghitung ketuntasan belajar siswa Untuk menghitung ketuntasan belajar siswa digunakan rumus sebagai berikut:

$$
P i=\frac{F i}{n} x 100 \%
$$

Keterangan:

$\mathrm{Pi}=$ proporsi dari kategori tertentu

Fi $=$ frekuensi mutlak dari kategori tertentu

$\mathrm{n} \quad=$ jumlah responden

Hasil analisis deskripsi tersebut

dikategorikan dengan menggunakan skala likert berikut ini.

Tabel 3.4

Kategori Persentase Nilai

\begin{tabular}{|c|c|c|}
\hline Persentase & Nilai & Kategori \\
\hline $80-100 \%$ & A & baik sekali \\
\hline $70-79 \%$ & B & Baik \\
\hline $60-69 \%$ & C & cukup \\
\hline $50-59 \%$ & D & rendah \\
\hline $0-4 \%$ & E & sangat rendah \\
\hline
\end{tabular}

\section{HASIL PENELITIAN DAN PEMBAHASAN}

Penelitian ini merupakan penelitian deskriptif kuantitatif. Penelitian ini menggunakan alat pengumpul data berupa tes uraian mengidentifikasi nilai-nilai dan kebahasaan dalam cerpen. Dari 32 orang siswa yang mengikuti tes mengidentifikasi nilai-nilai dan kebahasaan dalam cerpen, selanjutnya adalah memberikan skor pada masing-masing indikator penilaian. Cara yang dilakukan dalam pengolahan data adalah menentukan penilaian kemampuan mengidentifikasi nilai-nilai dan kebahasaan dalam cerpen.

\section{Kemampuan Mengidentifikasi Nilai-Nilai dan Kebahasaan dalam Cerpen Pada Indikator Nilai Moral Siswa Kelas X SMA Swasta Pelita Bulu Cina}

Deskriptor penilaian dalam indikator Nilai Moral disajikan pada tabel distribusi frekuensi dan persentase sebagai berikut. Berdasarkan tabel kriteria penilaian pada indikator nilai moral diperoleh gambaran bahwa, pada deskriptor menyebutkan dan menjelaskan seluruh nilai moral yang terdapat pada cerpen sebanyak 13 orang $(40,63 \%)$, deskriptor menyebutkan dan menjelaskan sebagian nilai moral yang terdapat pada cerpen sebanyak 19 orang $(59,38 \%)$.

2. Kemampuan Mengidentifikasi Nilai-Nilai dan Kebahasaan dalam Cerpen Pada Indikator Nilai Budaya Siswa Kelas X SMA Swasta Pelita Bulu Cina 
Tabel 4.3

istribusi Kriteria Kema mpuan Mengid entifikasi Nilai-Nilai d an Kebahasaan dalam Cerpen Pada Indikator Nilai Budaya

\begin{tabular}{|c|l|c|c|}
\hline No & Deskriptor Penilaian $(\mathrm{X})$ & Frekuensi $(\mathrm{F})$ & Persentase \\
\hline 1 & $\begin{array}{l}\text { Menyebutkan dan } \\
\text { menjelaskan seluruh nilai } \\
\text { budaya yang terdapat pada } \\
\text { cerpen }\end{array}$ & $85,81 \%$ \\
\hline 2 & $\begin{array}{l}\text { Menyebutkan dan } \\
\text { menjelaskan sebagian } \\
\text { nilai budaya yang terdapat } \\
\text { pada cerpen }\end{array}$ & 23 & $74,19 \% 6$ \\
\hline 3 & $\begin{array}{l}\text { Hanya menyebutkan } \\
\text { seluruh nilai budaya yang } \\
\text { terdapat pada cerpen }\end{array}$ & 0 & $0 \% 6$ \\
\hline & Jumlah & 32 & $100 \%$ \\
\hline
\end{tabular}

Berdasarkan tabel kriteria penilaian pada indikator nilai budaya tersebut diperoleh gambaran bahwa, pada deskriptor menyebutkan dan menjelaskan seluruh nilai budaya yang terdapat pada cerpen sebanyak 8 orang $(25,81 \%)$, deskriptor menyebutkan dan menjelaskan sebagian nilai budaya yang terdapat pada cerpen sebanyak 23 orang $(74,19 \%)$.

Kemampuan Mengidentifikasi nilai-nilai dan kebahasaan dalam cerpen Pada Indikator Nilai Sosial Siswa Kelas X SMA Swasta Pelita Bulu Cina

Tabel 4.4

Distribusi Kriteria Kemampuan Mengidentifikasi Nilai-Nilai d an

Keb ahasaan dalam Cerpen Pada Indikator Nilai Sosial

\begin{tabular}{|c|l|c|c|}
\hline No & Deskriptor Penilaian $(\mathrm{X})$ & Frekuensi $(\mathrm{F})$ & Persentase \\
\hline 1 & $\begin{array}{l}\text { Menyebutkan dan } \\
\text { menjelaskan seluruh nilai } \\
\text { sosial yang terdapat pada } \\
\text { cerpen }\end{array}$ & 19 & $59,38 \%$ \\
\hline 2 & $\begin{array}{l}\text { Menyebutkan dan } \\
\text { menjelaskan sebagian } \\
\text { nilai sosial yang terdapat } \\
\text { pada cerpen }\end{array}$ & 12 & $37,50 \% 6$ \\
\hline 3 & $\begin{array}{l}\text { Hanya menyebutkan } \\
\text { seluruh nilai sosial yang } \\
\text { terdapat pada cerpen }\end{array}$ & 1 & $3,13 \%$ \\
\hline & Jumlah & 32 & $100 \% 6$ \\
\hline
\end{tabular}

Berdasarkan tabel kriteria penilaian pada indikator nilai sosial tersebut diperoleh gambaran bahwa, pada deskriptor menyebutkan dan menjelaskan seluruh nilai sosial yang terdapat pada cerpen sebanyak 19 orang $(59,38 \%)$, deskriptor menyebutkan dan menjelaskan sebagian nilai sosial yang terdapat pada cerpen sebanyak 12 orang $(37,50 \%)$, dan deskriptor hanya menyebutkan seluruh nilai sosial yang terdapat pada cerpen sebanyak 1 orang $(3,13 \%)$.

Kemampuan Mengidentifikasi Nilai-Nilai dan Kebahasaan dalam Cerpen Pada Indikator Nilai Keagamaan Siswa Kelas X SMA Swasta Pelita Bulu Cina

Deskriptor penilaian dalam indikator nilai keagamaan disajikan pada tabel distribusi frekuensi dan persentase sebagai berikut. 
Tabel 4.5

Distribusi Kriteria Kemampuan Mengid entifikasi Nilai-Nilai dan Kebahasaan dalam Cerpen Pada Ind ikator Nilai Keaga maan

\begin{tabular}{|c|l|c|c|}
\hline No & Deskriptor Penilaian $(\mathrm{X})$ & Frekuensi $(\mathrm{F})$ & Persentase \\
\hline 1 & $\begin{array}{l}\text { Menyebutkan dan } \\
\text { menjelaskan seluruh nilai } \\
\text { keagamaan yang terdapat } \\
\text { pada cerpen }\end{array}$ & 12 & $37,50 \%$ \\
\hline 2 & $\begin{array}{l}\text { Menyebutkan dan } \\
\text { menjelaskan sebagian } \\
\text { nilai keagamaan yang } \\
\text { terdapat pada cerpen }\end{array}$ & 20 & $62,50 \% 6$ \\
\hline 3 & $\begin{array}{l}\text { Hanya menyebutkan } \\
\text { seluruh nilai keagamaan } \\
\text { yang terdapat pada cerpen }\end{array}$ & 0 & $0 \% 6$ \\
\hline & Jumlah & 32 & $100 \%$ \\
\hline
\end{tabular}

Berdasarkan tabel kriteria penilaian pada indikator nilai keagamaan tersebut diperoleh gambaran bahwa, pada deskriptor menyebutkan dan menjelaskan seluruh nilai keagamaan yang terdapat pada cerpen sebanyak 12 orang $(37,50 \%)$, deskriptor menyebutkan dan menjelaskan sebagian nilai keagamaan yang terdapat pada cerpen sebanyak 20 orang $(62,50 \%)$.

Kemampuan Mengidentifikasi Nilai-Nilai dan Kebahasaan dalam Cerpen Pada Indikator Nilai Pendidikan Siswa Kelas X SMA Swasta Pelita Bulu Cina

Deskriptor penilaian dalam indikator nilai pendidikan disajikan pada tabel distribusi frekuensi dan persentase sebagai berikut.

Tabel 4.6

Distribusi Kriteria Kemampuan Mengidentifilasi Nilai-Nilai d a Kebahasaan dalam Cerpen Pada Indikator Nilai Pend idikan

\begin{tabular}{|c|l|c|c|}
\hline No & Deskriptor Penilaian $(X)$ & Frekuensi $(F)$ & Persentase \\
\hline 1 & $\begin{array}{l}\text { Menyebutkan dan } \\
\text { menjelaskan seluruh nilai } \\
\text { pendidikan yang terdapat } \\
\text { pada cerpen }\end{array}$ & 11 & $34,38 \% 6$ \\
\hline 2 & $\begin{array}{l}\text { Menyebutkan dan } \\
\text { menjelaskan sebagian } \\
\text { nilai pendidilan yang } \\
\text { terdapat pada cerpen }\end{array}$ & 21 & $65,63 \%$ \\
\hline 3 & $\begin{array}{l}\text { Hanya menyebutkan } \\
\text { seluruh nnilai pendidikan } \\
\text { yang terdapat pada cerpen }\end{array}$ & 0 & $0 \% 6$ \\
\hline & Jumlah & 32 & $100 \%$ \\
\hline
\end{tabular}

Berdasarkan tabel kriteria penilaian pada indikator nilai pendidikan tersebut diperoleh gambaran bahwa, pada deskriptor menyebutkan dan menjelaskan seluruh nilai pendidikan yang terdapat pada cerpen sebanyak 11 orang $(34,38 \%)$, deskriptor menyebutkan dan menjelaskan sebagian nilai pendidikan yang terdapat pada cerpen sebanyak 21 orang $(65,63 \%)$.

Kemampuan Mengidentifikasi Nilai-Nilai dan Kebahasaan dalam Cerpen Pada Indikator Penggunaan Majas Siswa Kelas X SMA Swasta Pelita Bulu Cina

Deskriptor penilaian dalam indikator penggunaan majas disajikan pada tabel distribusi frekuensi dan persentase sebagai berikut. 


Tabel 4.7
$\begin{gathered}\text { Distribusi Kriteria Kema mpuan Mengid entifikasi Nilai-Nilai dan } \\
\text { Kebahasaan dalam Cerpen Pada Ind ikator Penggunaan Majas }\end{gathered}$
\begin{tabular}{|c|l|c|c|}
\hline No & \multicolumn{1}{|c|}{ Deskriptor Penilaian (X) } & Frekuensi (F) & Persentase \\
\hline 1 & $\begin{array}{l}\text { Menyebutkan dan menjelaskan } \\
\text { seluruh penggunaan majas yang } \\
\text { terdapat pada cerpen }\end{array}$ & 19 & $59,38 \%$ \\
\hline 2 & $\begin{array}{l}\text { Hanya menyebutkan dan } \\
\text { menjelaskan sebagian } \\
\text { penggunaan majas yang terdapat } \\
\text { pada cerpen }\end{array}$ & 13 & $40,63 \%$ \\
\hline 3 & $\begin{array}{l}\text { Hanya menyebutkan dan } \\
\text { menjelaskan sedikit penggunaan } \\
\text { majas yang terdapat pada cerpen }\end{array}$ & 0 & $0 \%$ \\
\hline & Jumlah & 32 & $100 \%$ \\
\hline
\end{tabular}

Berdasarkan tabel kriteria penilaian pada indikator penggunaan majas tersebut diperoleh gambaran bahwa, pada deskriptor menyebutkan dan menjelaskan seluruh penggunaan majas yang terdapat pada cerpen sebanyak 19 orang $(59,38 \%)$, deskriptor hanya menyebutkan dan menjelaskan sebagian penggunaan majas yang terdapat pada cerpen sebanyak 13 orang $(40,63 \%)$.

Kemampuan Mengidentifikasi Nilai-Nilai dan Kebahasaan dalam Cerpen Pada Indikator Penggunaan Konjungsi Siswa Kelas X SMA Swasta Pelita Bulu Cina

Deskriptor penilaian dalam indikator penggunaan konjungsi disajikan pada tabel distribusi frekuensi dan persentase sebagai berikut.

Tabel 4.8

Distribusi Kriteria Kemampuan Mengid entifikasi Nilai-Nilai dan

Kebahasaan dalam Cerpen Pada Indikator Penggunaan Konjungsi

\begin{tabular}{|c|l|c|c|}
\hline No & \multicolumn{1}{|c|}{ Deskriptor Penilaian $(\mathrm{X})$} & Frekuensi (F) & Persentase \\
\hline 1 & $\begin{array}{l}\text { Dapat menceritakan seluruh } \\
\text { urutan peristiwa atau alur } \\
\text { kejadian dalam cerpen }\end{array}$ & 19 & $59,38 \%$ \\
\hline 2 & $\begin{array}{l}\text { Hanya menceritakan sebagian } \\
\text { urutan peristiwa atau alur } \\
\text { kejadian dalam cerpen }\end{array}$ & 13 & $40,63 \%$ \\
\hline 3 & $\begin{array}{l}\text { Tidak dapat menceritakan } \\
\text { seluruh urutan peristiwa atau } \\
\text { alur kejadian dalam cerpen }\end{array}$ & 0 & $0 \% 6$ \\
\hline & Jumlah & 32 & $100 \%$ \\
\hline
\end{tabular}

Berdasarkan tabel kriteria penilaian pada indikator penggunaan konjungsi tersebut diperoleh gambaran bahwa, pada deskriptor dapat menceritakan seluruh urutan peristiwa atau alur kejadian dalam cerpen sebanyak 19 orang (59,38\%), deskriptor hanya menceritakan sebagian urutan peristiwa atau alur kejadian dalam cerpen sebanyak 13 orang $(40,63 \%)$.

\section{Pengolahan Data}

Mengubah skor mentah siswa dari tes hasil kemampuan mengidentifikasi nilai-nilai dan kebahasaan dalam cerpen siswa Kelas X SMA Swasta Pelita Bulu Cina Tahun Pelajaran 2018/2019, dengan menggunakan tabel persentase, seperti yang terdapat di bawah ini : 
Tabel 4.9

Persentase Indikator Yang Dinilai Dari Kema mpuan Mengid entifikasi Nilai-Nilai dan Kebaha saan dalam Cerpen Siswa Kelas X

SMA Sir asta Pelita Bulu Cina Tahun Pelajaran 2018 / 2019

\begin{tabular}{|c|l|l}
\hline No & \multicolumn{1}{|c|}{ Indikator yang Dinilai } & \multicolumn{1}{c}{ Persentase } \\
\hline 1 & Nilai Moral & $\frac{77}{548} \times 100 \%=14,05 \%$ \\
\hline 2 & Nilai Budaya & $\frac{72}{548} \times 100 \%=13,14 \%$ \\
\hline 3 & Nilai Sosial & $\frac{82}{548} \times 100 \%=14,96 \%$ \\
\hline 4 & Nilai Keagamaan & $\frac{76}{548} \times 100 \%=13,87 \%$ \\
\hline 5 & Nilai Pendidikan & $\frac{75}{548} \times 100 \%=13,69 \%$ \\
\hline 6 & Penggunaan Mhjas & $\frac{83}{548} \times 100 \%=15,15 \%$ \\
\hline 7 & Penggunaan Konjungsi & $\frac{83}{548} \times 100 \%=15,15 \%$ \\
\hline & & \\
\hline
\end{tabular}

Dari tabel di atas jelas bahwa kemampuan siswa dalam mengidentifikasi nilai-nilai dan kebahasaan dalam cerpen untuk indikator nilai moral yaitu $14,05 \%$, indikator budaya yaitu $13,14 \%$, indikator nilai sosial yaitu $14,96 \%$, indikator keagamaan yaitu $13,87 \%$, indikator nilai pendidikan yaitu $13,69 \%$, indikator penggunaan majas yaitu $15,15 \%$, dan indikator penggunaan konjungsi yaitu $15,15 \%$.

Persentase yang diperoleh siswa dari indikator-indikator yang dinilai dalam kemampuan mengidentifikasi nilai-nilai dan kebahasaan dalam cerpen dapat dilihat lebih jelas pada histogram berikut ini :

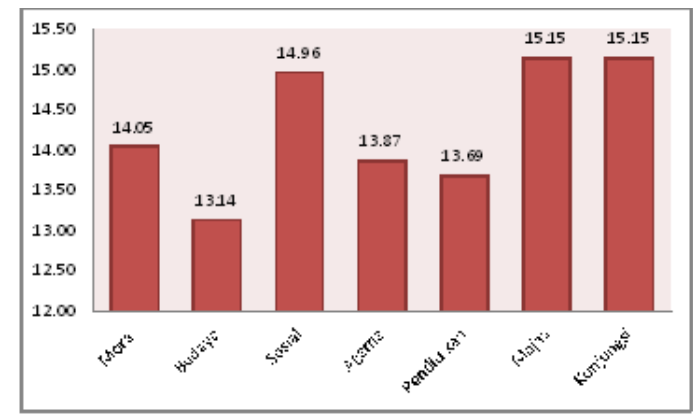

Gambar 4.1 Histogram persentase kemampuan mengidentifikasi nilai-nilai dan kebahasaan dalam cerpen

Menghitung mean rata-rata kemampuan mengidentifikasi nilai-nilai dan kebahasaan dalam cerpen oleh siswa Kelas X SMA Swasta Pelita Bulu Cina Tahun Pelajaran 2018/2019 dengan menggunakan rumus :

$$
\mathrm{M}=\frac{\text { Jumlah nilai keseluruha } \mathrm{n}}{\text { Jumlah siswa }}
$$




$$
\begin{aligned}
& M=\frac{2610}{32} \\
& M=81,55
\end{aligned}
$$

Berdasarkan perhitungan di atas dapat diketahui nilai rata-rata yang diperoleh siswa Kelas X SMA Swasta Pelita Bulu Cina Tahun Pelajaran 2018/2019 dalam kemampuan mengidentifikasi nilai-nilai dan kebahasaan dalam cerpen menggunakan teknik latihan terbimbing adalah 81,55.

Persentase siswa termasuk pada perangkat nilai kemampuan mengidentifikasi nilai-nilai dan kebahasaan dalam cerpen mengidentifikasi nilai-nilai dan kebahasaan dalam cerpen dapat dilihat lebih jelas pada tabel persentase berikut ini:

\section{Tabel 4.10}

Persentase Sisw a Pada Perangkat Nilai Kemampuan Mengidentifikasi NilaiNilai d an kebahasaan dalam Cerpen Siswa Kelas X SMA Šw asta Pelita Bulu Cina Tahun Pelajaran 2018/2019

\begin{tabular}{|c|l|c|c|}
\hline Angka & Ka tagori & Jumlah Siswa & Persentase \\
\hline $90-100$ & Baik Sekali & 11 & $34,38 \%$ \\
\hline $80-89$ & Baik & 21 & $65,63 \%$ \\
\hline $70-79$ & Cukup & 0 & $0 \%$ \\
\hline $50-59$ & Rendah & 0 & $0 \%$ \\
\hline $0-49$ & Sangat Rendah & 0 & $0 \%$ \\
\hline \multicolumn{2}{|c|}{ Jumlah } & $\mathbf{3 2}$ & $\mathbf{1 0 0 \%}$ \\
\hline
\end{tabular}

Untuk lebih jelasnya kategori yang diperoleh siswa mengenai kemampuan mengidentifikasi nilai-nilai dan kebahasaan dalam cerpen oleh siswa Kelas X SMA Swasta Pelita Bulu Cina Tahun Pelajaran 2018/2019 dapat dilihat pada histogram berikut ini :

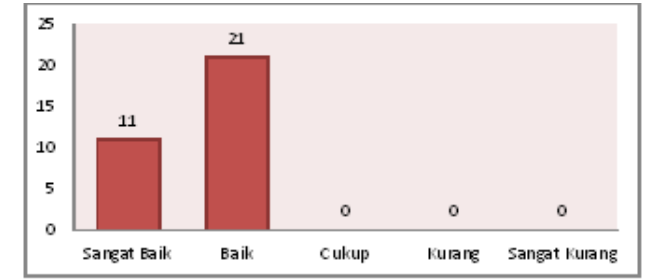

Gambar 4.2 Persentase ka tegori kemampuan mengidentifikasi nilai-nilai dan kebahasaan dalam cerpen

Berdasarkan data tersebut di atas telah diketahui nilai rata-rata kemampuan mengidentifikasi nilai-nilai dan kebahasaan dalam cerpen siswa Kelas X SMA Swasta Pelita Bulu Cina dengan pembulatan nilai rata-rata 81,55 . Setelah diperoleh nilai rata-rata yang diperoleh siswa Kelas X SMA Swasta Pelita Bulu Cina tahun pelajaran 2018/2019, selanjutnya membandingkan nilai rata-rata tersebut dengan teori Suparno dan M. Yunus yaitu:

$90-100 \%$ = baik sekali

$80-89 \%=$ baik

$70-79 \%=$ cukup

$<70 \%=$ kurang

Dengan demikian hasil penelitian ini menyatakan kemampuan mengidentifikasi nilai-nilai dan kebahasaan dalam cerpen menggunakan teknik latihan terbimbing siswa Kelas X SMA Swasta Pelita Bulu Cina tahun Pelajaran 2018/2019 berada pada kategori baik. 


\section{SIMPULAN}

1. Nilai rata-rata yang diperoleh dari mengidentifikasi nilai-nilai dan kebahasaan dalam cerpen oleh siswa Kelas X SMA Swasta Pelita Bulu Cina Tahun Pelajaran 2018/2019 adalah 81,55.

2. Hasil kemampuan mengidentifikasi nilai-nilai dan kebahasaan dalam cerpen siswa Kelas $X$ SMA Swasta Pelita Bulu Cina Tahun Pelajaran 2018/2019 berada pada kategori "baik".

\section{REFERENSI}

Arikunto, Suharsimi. 2006. Prosedur Penelitian Suatu Pendekatan Praktek. Jakarta: Rineka Cipta.

Cahyani, Isah. 2009. Pembelajaran Bahasa Indonesia. Jakarta: Dikjen Pendidikan Islam.

Chaer, Abdul. 2007. Kajian Bahasa. Jakarta : Rineka Cipta.

Kossasih. 2012. Dasar-dasar Keterampilan Bersastra. Bandung: Yrama Widya.

Nugraheni, Sri, Aninditya. 2012 Penerapan Strategi Cooperative Learning dalam Pembelajaran Bahasa Indonesia. Yogyakarta; Pustaka Insan Madani.

Nurgiyantoro, Burhan. 1995. Teori Pengkajian Fiksi. Yogyakarta: Gadjah Mada University Press.

Sudjana, Nana. 2010. Evaluasi Proses dan Hasil Pembelajaran. Jakarta: Bumi Aksara.

Semi, Atar. 1993. Metode PenelitianSastra. Bandung: Angkasa.

Suryohadiprojo, Letnan TNI Sayidima dkk. 1980. Bahasa dan Sastra. Jakarta: Pusat.

Sudijman.2006. Kamus Istilah Sastra. Jakarta: Universitas Indonesia.

Tarigan, Henry Guntur. 2009. Membaca Sebagai Suatu Keterampilan Berbahasa. Bandung: Angkasa Bandung. 